\title{
Assertion of Dimasa Identity: A Case Study of Assam
}

\author{
Bidhan Barman ${ }^{1}$ \\ ${ }^{1}$ Research Scholar, Department of Political Science, Assam University, Silchar-11, Assam
}

\begin{abstract}
Assam has been the meeting place of different races and consequently a large number of ethnic groups have been residing in Assam. The process of ethnic assimilation remained incomplete in Assam. Situation did not change after independence. The policy of segregating the people was continued on the one hand, and on the other, state power and the fruits of development were monopolized by the elites. Tribals and other marginalized sections were kept out of the narrow field of employment. At this juncture the movement to install Assamese as the official language of the state deeply disturbed the tribals and linguistic minorities living in the state. It was taken by the elite of those sections as a move to establish permanent monopoly of power in the state for Assamese. The rising expectations of different sections and the injustice led to militancy and fanned the flames of separatism of different types. Most ethnic groups reconstructed their past so as to constitute a national heritage resulting in what is referred to as the politics of identity. The present study is an attempt to understand historical background of the assertion of Dimasa ethnic identity in Assam.
\end{abstract}

Key Words: Cachar, Dimasa, Ethnic groups, Identity, Tribal.

\section{Introduction}

The identity assertion of various ethnic groups has been articulated through religion, language, culture, region, caste and race. This problem is very much acute in Assam. The different groups inhabiting this state have been launching movement either for the creation of separate or autonomous state on the basis of their ethnic identities or for special constitutional safeguards of their respective identities[1].Though at the beginning, they started their assertion with non-political issues such as the development of their language and culture, the uneven economic development gave it a political direction in the subsequent period. As a result, they have become assertive of their political right and started movement for adequate share of political power in order to maintain their distinct identities. The case of the Dimasas is not an exception.

The Dimasas belong to the Indo-mongloid group of people and have similarities with other members of Bodo group such as Garos, Kachari, Mech and Rabhas. The Dimasa peoples are the inhabitants of North Cachar Hills Autonomous District Council, Karbi Anglong Autonomous District Council, Cachar District, Nagaon District of Assam and the Dhansiri region of Nagaland State. The Dimasas ruled this vast tract with Dimapur (now in Nagaland state) as their capital. They shifted their capital to Maibang in North Cachar Hills in mid sixteenth century. The Dimasa kingdom during this period included North Cachar Hills and the greater part of Nagaon district. Finally, the Dimasas shifted their capital to Khaspur in the plains of Cachar district. The present district of Dima Hasao District (earlier it was known as -North Cachar Hills District) formed a part of ancient Kamarupa and later in the medieval period, it formed the northern part of the Kachari kingdom known as Herambarajya. In comparatively recent times following the death of Govinda Chandra Narayana, (1813-1830 A.D) the Raja (king) of Cachar, the British annexed the district of Cachar to the East India Company's territory on 14th August 1832 by a Proclamation. Between 1832 and 1881 distribution and redistribution of old Dimasa territory took place and in 1881 North Cachar Hills was made a subdivision of Cachar. In 1951 North Cachar Hills was separated from Cachar and it became a subdivision of United Mikir and North Cachar Hills District. It was only in 1971 that North Cachar Hills(now known as Dima Hasao Autonomous District Council) was made a full-fledged district of Assam with its headquarters at Haflong with one autonomous District Council. At present the Dimasas are known by different names in different districts and states. They are:

> Dimasa (Kachari) Schedule Tribe (Hills), in Dima Hasao (North Cachar Hills District) and Karbi Anglong District.

> Barman in Cachar, Schedule Tribe (Plains), in Cachar District.

$>$ Hojai Kachari, Schedule Tribe (Plains), in Nagaon District.

$>$ Kachari, Schedule Tribe (Hills) in Nagaland state.

$>$ The Tangmi or Rukhini Barmans, Scheduled Tribe. (Plains) community of Karimganj District.

These all tribes belong to same community. i.e. Dimasa. Recognition of Dimasa community by different names in different districts and states as mentioned above which further created troubles, misunderstandings, and disintegrations within the Dimasa society. The All Dimasa Students Union has been demanding the 
recognition of the Barmans in Cachar, Scheduled Tribe (Plains) community of Cachar District, the Tangmi or Rukhini Barmans, Scheduled Tribe. (Plains) community of Karimganj District, the Hojai Kachari Scheduled Tribe (Plains) community of Nagaon District of Assam and the Kacharis, Scheduled Tribe (Hills) community of Nagaland as the 'Dimasa Kachari' with Hills or Plains where necessary through constitutional amendment for the proper identification of the community of same language and culture. It is one of the important demands of the All Dimasa Students' Union (ADSU) that to recognize their community all over the North East India is to be recognized as 'Dimasa' by amending the constitution. As far as the provision of Schedule Tribe Hills and Plains facility is concerned, let them enjoy the ST (Hills) and ST (Pains) facility as they are enjoying at present in different districts of Assam and Nagaland. But the whole Dimasa community should be recognized by one name viz. Dimasa.

The Dimasas have also another complain that till date the Dimasa people have never been provided with the opportunity to send a member-representative from their community either to the House of State Assembly or to the Parliament from any constituency of a district of any state other than Dima Hasao (North Cachar Hills) to ventilate their problems and grievances for remedies. But the non-tribals who migrated to their ancestral homeland and over-populated them have been freely enjoying such benefits and all other economic rights and facilities ever since the British rule. The Dima Hasao (North Cachar Hills) has now been spared with only one seat in the State Assembly of Assam. No Dimasa people of other districts either of the State of Nagaland or of Assam has been provided with such opportunities. The re-organization of districts and states has resulted in dividing the Dimasas from their own ancestral homeland. The identity, integrity, language and culture of the Dimasa people are now threatened. The present study is an attempt to understand the nature, growth and support base of the assertion of Dimasa identity in Assam

\section{Review Of Literature}

There are a number of scholarly works on Dimasas. But most of the works give either a historical account of the Dimasas or socio-cultural aspect of the Dimasa tribe. In this category comes.

S. K. Barpujari's 'History of the Dimasas'[2] (From the earliest time to 1896 A.D.) is pioneering attempt to present in a comprehensive manner the history of the Dimasas covering almost all the aspects from very early times to the fall of their kingdom and its subsequent incorporation to the British colonial administration. Sir Edward Gait, in his book 'A History of Assam'[3]described the Kacharis or the Dimasas as the aborigines, or earliest known inhabitants of the Brahmaputra Valley. Sir Gait described the rise and fall of the Dimasa kings. Suhas Chatterjee in his work 'A Socio Economic History of South Assam' [4]gave a brief description of the Kachari Kingdom. He explained why the Dimasa Kahcaris had to shift their capital from Dimapur to Maibong, to present Dima Hasao Autonomous District Council and lastly to Khaspur (it is situated in cachar district of Assam). Debabrata Dutta's work 'History of Assam' [5]also gives a brief description of the origin, development and decay of Dimasa-Kachari Kingdom. J.B. Bhattacharjee's 'Cachar Under British Rule in North East India'[6]is a comprehensive history of Cachar from 1765 to 1947. Nicholas Rhodes and Shankar $\mathrm{Kr}$. Bose conducted a study 'A History of the Dimasa-Kacharis as seen through Coinage'[7]. In this work, the authors discussed the Dimasa kingdom (Heramba kingdom) and the ruling tribe through the coinage and also about the uses of coins in Dimasa kingdom. The history Manipuris in Kachar, is dealt with in this work. Unpendrachandra Guha's 'Cacharer Itibritta' [8] (A History of Cachar), dealt with the history of Cachar. In his study, Guha narrated the language and oral tradition of Dimasa Kacharis and also with the practices followed by the Kachari Kings. P.S. Dutta's 'Autonomy Movements in Assam'[9] is compilation of memoranda submitted by different groups at different point of time seeking to have autonomy in their own affairs.

It is thus clear that the works made on Dimasas are mainly historical work. They do not deal with the politics that is in force at this moment. In view of this limitation, the present study is important and pioneering one.

\section{Methodology}

The required information was obtained from books, memoranda, pamphlets and other archival records both official and non-official. Besides, some persons having knowledge of the subject were also interviewed.

\section{Findings Of Historical Analysis Of The Assertion Of Dimasa Identity In Assam}

Until 1961, the Dimasas were treated as a sub-tribe of the Kachari tribes. In the 1961 census, they were classified as a separate tribe. Before the introduction of the District Council, the Dimasas were not much concerned of the national political situation. The life of average Dimasas was confined to the boundaries of their respective villages. Repeated migrations had already made the community isolated and conservative. The people who were once the ruling power of a large tract of Assam had confined themselves in their shells and the Dimasas living in isolated pockets had lack of contacts with the greater world.[10] Though living in isolation, the Dimasas had a vague sense of pan-Dimasa identity. While referring to the oblivious past, the 
Dimasas even today feel proud of their past glory. Dimasa folk songs lament the tragedy of migration from Dimapur and refer to the vision of reunion.

When the enlightened Dimasas heard of the impending constitutional changes in 1947 they joined hands with the other tribal leaders of N.C. Hills and formed the Tribal Council under leadership of Mr. H.M. Haflongbar. Mr. Haflongbar and other members of the Dimasa community who joined this Tribal Council represented the emerging middle class interest of the society. Many of them had come into contact with the traders and contractors coming from the plains and had started their career as petty contractors, suppliers or as business partners with the plains people. The responsibility of safeguarding the Dimasa interest naturally fell on them and they submitted a memorandum to the Bordoloi committee and demanded the appointment of a boundary commission to fix the boundaries of N.C. Hills in such a way that all the Dimasas living in the adjoining areas could be brought together. The Tribal Council also demanded that only bonafide inhabitants of the area should be permitted to participate in the political life of the sub-division and law and regulation passed by the Central or Provincial Legislature should not be applied to the hill areas without the consent of the M.L.A.s from the area concerned. Along with these political demands, the Tribal Council also demanded that there should not be any interference with the cultural life of the tribes. Thus the first vocal assertion of the identity of the Dimasas and other tribal communities of N.C. Hills dates back to the memorandum of the Tribal Council. During this transitional period the vast majority of the Dimasas were in the dark about the political developments taking place in the country.

During the first twenty years of the District Council, the Dimasa elites were busy in the struggle for power and consequently, the developmental works of the District Council suffered a setback.[11] In spite of the Sixth Schedule, the Dimasas could not make much progress in the cultural field. Though there was a strong demand for the introduction of the Dimasa language at the primary level, the District Council could not implement it. Dimasa text book for the primary classes were published by the Assam Text Book Production and Publication Board in 1972. But these books remained in the godowns of the District Council. In spite of the language has always been a mobilizing force for any group of people, the Dimasa elites could not make much progress in convincing the authorities to give due place to their language.

Dimasa Jalairaoni Hoshom (Dimasa Youth Organisation), a non-political forum of educated Dimasa youth was formed in 1972. It is a cultural organisation with its headquarter at Haflong. Since its inception it has been demanding the preservation of Dimasa historical monuments and the adoption of Dimasa language at the primary level in N.C. Hills. Dimasa historical monuments of Dimapur and Maibong are in a deplorable condition and the educated Dimasa youths are very agitated on this point. In 1978, the District Council gave some new settlements to a few non-tribals which caused resentment among the Dimasas. In its annual general meeting on 24-6-79 'Dimasa Jalairaoni Hosom' passed a resolution urging upon the authority to stop giving undesirable settlement to outsiders.

Dimasa National Organisation was formed in 1979. The organisation in its first general session held in March 11,1979 passed a resolution demanding the preservation of ancient relics and monuments of the Kachari kings lying in various places of Assam and other parts of North Eastern States especially at Dimapur, Maibong and Khaspur. The executive committee of this organisation consists of Dimasas belonging to the plains and the hills. Important Dimasa personalities like Sri Nandamohan Barman (President), Sri Brojendra Langthasa (General Secretary) were connected with this organisation and this was the first attempt to unite all the Dimasa living in different areas under a common umbrella. Dimasa lawyers like Sri Anil Kumar Barman of Cachar, the then Minister of Assam Sri Sonaram Thaosen of N.C. Hills and the delegates from Nagaland pledged to work for a cultural and social unification of all the Dimasas.

Dimasas of Cachar District formed 'Nikil Cachar Haidimba Barman Samity' in December 31, 1945 at Bijoypur, in the present Borkhola Constituency. It is the oldest organization of the Dimasa community, not only in Barak Valley but also among the other Dimasa organizations in Assam. The Barman Kachari is one of the important tribal communities of Assam who belong to the Bodo race. They are mainly concentrated in the Cachar District of Assam. The converted section of the Dimasa Kacharis are known as Barman in the district of Cachar. Linguistically they belong to the Tibeto-Burman family. According to their own version the aristocratic families who accompanied the fugitive Kachari king from Maibang to Khaspur are the Barmans of Cachar. According to 1971 census their population was 13,210.Nikhil Cachar Haidimba Barman Samiti, put forward a political demand in 1980 for the reorganization of the Dimasa speaking areas of the North East. This organization believes in the concept of greater Dimasa nationality and opines that the existence of the Dimasas will be in danger unless all the Dimasas are brought under a single administrative unit. Consequently, basing upon geographical facts and historical evidence, the organisation demands that the southern part of Nagaon district including Howraghat, Jamunamukh, Dabaka, Lanka, Hojai, Namti, Jogijan and the area from Dimapur to Dhansiri should be included in the proposed administrative unit. It also threatened prolonged agitation in the event of the non-fulfillment of its demand. Though in practice the organisation, did not take the path of agitation, its demand for the reorganisation of the Dimasa speaking areas has once again revived 
the urge for political and cultural supremacy among the Dimasas of Assam. In the event of any future reorganisation of the North-East, the organisation may renew its claim.

The Dimasas of Cachar District also formed 'Dimasa Sanskriti Parishad' in 1975 to promote the cultural life of the Dimasas of Cachar. It also proposed to build a 'Dimasa Sanskriti Bhavan' at Silchar which would be a center for the promotion of Dimasa art and culture. It was due to the persistent endeavour of this Parishad that the Archaeological Survey of India took necessary action for the preservation of the 'Bishnu Mandir' of Borkhola 'Barohali Pukur' in Bihara and the two 'Shibtilas' of Haritikar and Sonai in Cachar. Dimasa Sanskriti Parishad also demanded for the introduction and accommodation of Dimasa Programme in the Silchar Doordarshan Kendra. Dimasa Sanskriti Parishad claims that the Dimasas are indigenous community of Cachar District and was the ruler of erstwhile princely state of Cachar and it cites the remains of ancient monuments at different places of the districts as evidences. In consideration of the above facts, programmes in Dimasa language was introduced in the All India Radio, Silchar at the time of its inception in 1972 and since then the programme at Silchar Radio Station has been continuing and nicely covering the areas of Barak Valley including N.C. Hills and Karbi Anglong District. The Silchar Doordarshan Kendra was established in 1992, but the programmes of Dimasa community are yet to be introduced and accommodated. As a result, Dimasa Sanskriti Parishad demanded to initiate action for introduction and accommodation of Dimasa programme to the Station Director, Silchar Doordarshan Kendra, on 7th August, 2003.

Dimasa Sanskriti Parishad also submitted a memorandum to Sri Tarun Gogoi, the Chief Minister of Assam, vehemently opposing the naming of third Barak Bridge at Ranighat (in cachar district), after late Altaf Hussain Mazumder Ex. Minister, P.W.D. Assam. Ranighat is a historical place where queen Induprova built a temporary palace and lived there after the assassination of her husband Raja Govindachandra, the last Dimasa king of the erstwhile princely state of Cachar. The 'Rani' (queen) used the ghat for which the place still goes by the name of Ranighat. For this reason the Dimasa Sanskriti Parishad has been demanding for naming the bridge as Rani Induprova Bridge since the laying of foundation stone of the bridge.

In 1991 the Dimasa Students organized themselves under All Dimasa Students' Union (ADSU). The All Dimasa Students Union has been demanding for creation of a separate full fledged state 'Dimaraji' by incorporating all the territories that were included in the ancient Dimasa Kachari Kingdom so as to enable them to enjoy all constitutional rights and privileges to bring all round developments. The All Dimasa Students' Union and the Dimaraji Revival Demand Committee jointly submitted a memorandum to Shri P.V. Narasimha Rao, Hon'ble Prime Minister of India, New Delhi in 1996, demanding a separate homeland for the Dimasas.

However, to press their demand the All Dimasa Students Union has been adopting the techniques of organizing bandh, dharnas, road blockade, rally, etc. The All Dimasa Students Union are getting support from other organizations. When ADSU called for 36 hour Dimaraji bandh/strike on 6th November 2007, the organizations of different communities in Barak Valley that have come forward to support the Dimaraji bandh, included Barak Valley Khasi Jaintia Welfare Association, Bishnupriya Gona Sangram Parishad, Barak Valley Tribal Rights Protection Front, All Barak Valley Tribal Students Federation, Cachar Tea Tribes Union, All Manipuri Students Union and also from Bihara Young Bengali Association and Nepali Union of Cachar.

Besides the constitutional path, a violent or so called militant path surfaced with the formation of Dimasa National Security Force (surrendered in 1994) and Dima Halam Daogah (DHD) in early nineties and added a new dimension to the politics of identity of the Dimasas. The emergence of these militant outfits can be ascribed partly to the no-responsive attitude of the government to the constitutional agitational path followed by the Dimasas and partly to the politics of expediency of the dominant class. The DHD came into being with the vow to create 'Dimaraji', i.e., a Dimasa State comprising the districts of N.C. Hills, Karbi Anglong and Cachar and part of the district of Nagaon in Assam and also part of Dimapur in Nagaland. But within a short time, differences developed among the DHD cadres centering mainly around the techniques to be followed to pursue the demand. This ultimately resulted in a split. A faction led by Dilip Nunisa signed Ceasefire Agreement with the Government of India on January 1, 2003 and thereafter abjured violence till date. Another faction led by Jowel Garlosa. The another group came to be known as DHD (Jowel) or Black Widow. The DHD (Jowel) has surrendered and sign a ceasefire agreement with the government of India on October 2, 2009. Both the insurgent groups of the DHD claim to be struggling for 'Dimaraji', the only solution, they consider to the problem of the Dimasas.

But the 'Dimaraji' of their perception resulted in making other ethnic groups, especially the Hmars living in the district of North Cachar Hills and the Karbis living in the district of Karbi Anglong, suspicious. They apprehended that if the DHD succeed in getting its demand for 'Dimaraji', fulfilled, they would be marginalised and would come under Dimasa domination. Consequently, they opposed the demand. Their opposition strained the relationship between the Dimasas on the one hand, and the Hmars and the Karbis on the other. This strained relationship resulted in conflagration, especially in the districts of N.C. Hills and Karbi 
Anglong. There was violent clash between the Hmars and the Dimasas in 2003 and between the Karbis and the Dimasas in 2005. These ethnic clashes resulted not only in the loss of hundred of lives and properties worth crore of rupees, but gave birth to an uneasy relationship between the ethnic groups living in the N.C. Hills and Karbi Angong districts of Assam.

\section{Conclusion}

Thus, the assertion of Dimasa identity led to a unique and complicated situation. It created a rift not only between the different ethnic groups but also between Dimasas themselves causing uncertainty and tension in the two autonomous district councils Dima Hasao Autonomous District Council and Karbi Anglong Autonomous District Council of Assam.

\section{References}

[1]. Girin Phukon, Politics of Regionalism in Northeast India (Spectrum Publications, Guwahati, 1996).

[2]. S. K. Barpujari, History of the Dimasas (Autonomous Council, N.C. Hills District, Haflong, 1997).

[3]. Edward Gait, A History of Assam (Lawyer's Book Stall, Guwahati, 1926).

[4]. S. Chatterjee, A Socio Economic History of South Assam (Printwell Publishers, 2000).

[5]. Debabrata Dutta, History of Assam (Sribumi Publishing Company, Culcutta, 1995).

[6]. J.B. Bhattacharjee, Cachar under British Rule in North East India (Radiant Publishers, New Delhi, 1977).

[7]. N.G. Rhodes, and S.K. Bose, A History of the Dimasa-Kacharis -As seen Through Coinage, (Mira Bose, Dubri, 2006).

[8]. Upendrachandra Guha, Cacharer Itibritta (Parul Prakashani, Agartala, 2006).

[9]. P.S. Datta, Autonomy Movement in Assam (Omsons Publications, New Delhi, 1993).

[10]. P.S. Misra, Identity Consciousness among the Dimasas of Assam in B. Pakem (Ed.) Nationality, Ethnicity and Cultural Identity in Northeast India, Omsons Publications, New Delhi, 1990), p.192.

[11]. P.S. Misra: Dimasa-Kachari in Transition in J.B. Bhattacharjee (Ed.) Sequences of Development in North East India (Omsons Publications, New Delhi, 1989), p.142. 